\title{
ON THE OCCURRENCE OF $\alpha$-ACETOLACTATE DECARBOXYLASES AMONG MICROORGANISMS
}

by

\author{
SVEN ERIK GODTFREDSEN
}

Department of Chemistry, Carlsberg Laboratory

Gamle Carlsberg Vej 10, DK-2500 Copenhagen Valby

\section{HENNING LORCK}

LEO - Pharmaceutical Products

Industriparken, DK-2750 Ballerup

POUL SIGSGAARD

Department of Brewing Chemistry, Carlsberg Research Laboratory

Gamle Carlsberg Vej 10, DK-2500 Copenhagen Valby

Keywords: Acetoin, beer, beer maturation, 2,3-butanediol, diacetyl, screening

The ability to generate $\alpha$-acetolactate decarboxylase activity has been detected among bacteria but not among members of any other group of microorganisms. Among bacteria found to produce an $x$-acetolactate decarboxylase several, such as strains of Bacillus and Lactobacillus, are potential sources of decarboxylases which may be applied in brewing.

Abbreviations: ATCC $=$ American Type Culture Collection; GRAS $=$ Generally regarded as safe; NAD $=$ Nicotinamide adenine dinucleotide; NCIB = National Collection of Industrial Bacteria; VP = Voges - Proskauer. 


\section{INTRODUCTION}

The finding that the beer maturation process can be greatly accelerated with the aid of $\alpha$ acetolactate decarboxylase preparations from Enterobacter aerogenes has a number of important perspectives related to brewing (6). First of all, the possibility of interfering selectively with one of the key events of the beer maturation process - the removal of diacetyl and its precursor acetolactate as well as the congeners of these compounds 2,3-pentanedione and acetohydroxy butyrate may lead to a better understanding of the beer maturation process. Secondly, and perhaps most important, the possibility of accelerating the beer maturation process may be utilized to economical advantage in industrial beer production. Acetolactate decarboxylase preparations may thus be used as maturation aid to increase peak outputs of breweries during periods of high demand, and application of the decarboxylases may simplify the overall beer production process to such an extent that substantial investments may be saved if new breweries are designed in accordance with the simplified processes made feasible by use of the maturation aid.

In order to derive such potential advantages of acetolactate decarboxylases it is essential to have available microbial sources of decarboxylases with properties optimal for use in brewing. Preferably, the decarboxylase should possess a high stability and activity in freshly fermented or fermenting wort, and the source of the decarboxylase should have acceptance within the food industry besides allowing for an efficient production of the decarboxylase. Previously, $\alpha$ acetolactate decarboxylases have been detected in preparations of the bacteria Enterobacter aerogenes (7), Streptococcus diacetylactis (11), Leuconostoc citrovorum (11), Staphylococcus aureus (12), Lactobacillus casei (1), Pseudomonas fluorescens (2), Serratia marcescens (2), Lactobacillus brevis (2), and Streptococcus lactis (2). Only the $\alpha$-acetolactate decarboxylase from Enterobacter aerogenes has been purified and characterized (8) and a systematic study of the occurrence of $\alpha$-acetolactate decarboxylases among microorganisms aiming at identification of the most suitable source of the decarboxylase has not been carried out. As de- scribed in the present report, the decarboxylase activity is generated by a wide variety of bacterial strains some of which are promising sources of a decarboxylase to be applied in brewing.

\section{MATERIALS AND METHODS}

\subsection{Media}

The following media were used for cultivation of the various microorganisms tested as detailed below.

Medium 1: $\quad \mathrm{K}_{2} \mathrm{HPO}_{4}(7 \mathrm{~g} / \mathrm{l}), \mathrm{KH}_{2} \mathrm{PO}_{4}(3 \mathrm{~g} / \mathrm{l})$, $\mathrm{Na}_{3}$-citrate $(5 \mathrm{~g} / \mathrm{l}), \mathrm{MgSO}_{4}(0.1 \mathrm{~g} / \mathrm{l})$, $\left(\mathrm{NH}_{4}\right)_{2} \mathrm{SO}_{4}(1 \mathrm{~g} / \mathrm{l}), \mathrm{D}-(+)$-glucose $(10 \mathrm{~g} / \mathrm{l})$, yeast extract (Difco) $(5 \mathrm{~g} / \mathrm{l})$, tryptose $(5 \mathrm{~g} / \mathrm{l}), \mathrm{FeSO}_{4}(0.1 \mathrm{mg} / \mathrm{l})$, sodium borate $(0.2 \mathrm{mg} / \mathrm{l})$, $\mathrm{CoSO}_{4} \cdot 7 \mathrm{H}_{2} \mathrm{O}(0.1 \mathrm{mg} / \mathrm{l}), \mathrm{CuSO}_{4}$ $(0.01 \mathrm{mg} / \mathrm{l}), \mathrm{MnSO}_{4}(0.01 \mathrm{mg} / \mathrm{l})$, $\left(\mathrm{NH}_{4}\right)_{6} \mathrm{Mo}_{7} \mathrm{O}_{24} \quad(0.1 \mathrm{mg} / \mathrm{l})$, and $\mathrm{ZnSO}_{4}(0.2 \mathrm{mg} / \mathrm{l})$ in distilled water.

Medium 2: $\quad \mathrm{Na}_{3}$-citrate $(5 \mathrm{~g} / \mathrm{l})$, lactose $(20 \mathrm{~g} / \mathrm{l})$, peptone (Difco) $(10 \mathrm{~g} / \mathrm{l})$, yeast extract (Difco) $(15 \mathrm{~g} / \mathrm{l}), \mathrm{KH}_{2} \mathrm{PO}_{4}(0.5$ $\mathrm{g} / \mathrm{l}), \mathrm{MgSO}_{4} \cdot 7 \mathrm{H}_{2} \mathrm{O}(0.2 \mathrm{~g} / \mathrm{l})$, and Na-acetate $(2 \mathrm{~g} / \mathrm{l})$ in distilled water.

Medium 3: cooked meat (Difco) (1.25 g) in 10 $\mathrm{ml}$ boiled distilled water.

Medium 4: glycerol (7.5 g/l), corn-steep $(2.5 \mathrm{~g} /$ 1), $\mathrm{MgSO}_{4}(0.05 \mathrm{~g} / \mathrm{l}), \mathrm{KH}_{2} \mathrm{PO}_{4}(0.06$ $\mathrm{g} / \mathrm{l}), \mathrm{NaCl}(4 \mathrm{~g} / \mathrm{l}), \mathrm{CuSO}_{4}(4 \mathrm{mg} / \mathrm{l})$, $\mathrm{FeSO}_{4}(5 \mathrm{mg} / \mathrm{l}), \mathrm{D}$-(+)-glucose $(10$ $\mathrm{g} / \mathrm{l})$, and soya meal $(15 \mathrm{~g} / \mathrm{l})$ in distilled water.

Medium 5: glycerol (7.5 g/l), glucose (10 g/l), corn-steep ( $2.5 \mathrm{~g} / \mathrm{l})$, pepton (Difco) $(5 \mathrm{~g} / \mathrm{l}), \mathrm{MgSO}_{4}(0.05 \mathrm{~g} / \mathrm{l}), \mathrm{NaCl}(4$ $\mathrm{g} / \mathrm{l}), \mathrm{KH}_{2} \mathrm{PO}_{4}(0.06 \mathrm{~g} / \mathrm{l}), \mathrm{FeSO}_{4}(5$ $\mathrm{mg} / \mathrm{l})$, and $\mathrm{CuSO}_{4}(4 \mathrm{mg} / \mathrm{l})$ in distilled water.

Medium 6: D-(+)-glucose $(20 \mathrm{~g} / \mathrm{l})$, pepton (Difco) $(10 \mathrm{~g} / \mathrm{l})$, yeast extract (Difco) $(5$ $\mathrm{g} / \mathrm{l}), \mathrm{NaCl}(2 \mathrm{~g} / \mathrm{l}), \mathrm{KH}_{2} \mathrm{PO}_{4}(\mathrm{lg} / \mathrm{l})$, $\mathrm{K}_{2} \mathrm{HPO}_{4}(1 \mathrm{~g} / \mathrm{l}), \mathrm{MgSO}_{4} \cdot 7 \mathrm{H}_{2} \mathrm{O}$ $(0.5 \mathrm{~g} / \mathrm{l})$ and $\mathrm{CaCO}_{3}(3 \mathrm{~g} / \mathrm{l})$ in distilled water. 


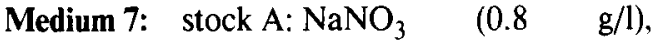 $\mathrm{MgSO}_{4} \cdot 7 \mathrm{H}_{2} \mathrm{O}(0.3 \mathrm{~g} / \mathrm{l})$ $\mathrm{MgCl}_{2} \cdot 6 \mathrm{H}_{2} \mathrm{O}(0.2 \mathrm{~g} / \mathrm{l})$, and $\mathrm{CaCl}_{2} \cdot 2 \mathrm{H}_{2} \mathrm{O}(0.15$ $\mathrm{g} / \mathrm{l})$ in distilled water}

stock B: $\mathrm{KH}_{2} \mathrm{PO}_{4}(0.87 \mathrm{~g} / \mathrm{l})$ and $\mathrm{Na}_{2} \mathrm{HPO}_{4}(0.7 \mathrm{~g} / \mathrm{l})$ in distilled water

stock $\mathrm{C}: \mathrm{H}_{3} \mathrm{BO}_{3} \quad(2.48 \quad \mathrm{~g} / \mathrm{l})$, $\mathrm{MnCl}_{2} \cdot 4 \mathrm{H}_{2} \mathrm{O}(1.39 \mathrm{~g} / \mathrm{l})$, and $\left(\mathrm{NH}_{4}\right)_{6} \mathrm{Mo}_{7} \mathrm{O}_{24}$. $4 \mathrm{H}_{2} \mathrm{O}(1 \mathrm{~g} / \mathrm{l})$ in distilled water

stock D: EDTA-Na $(2 \mathrm{~g} / \mathrm{l})$ and $\mathrm{FeCl}_{3} \cdot 6 \mathrm{H}_{2} \mathrm{O}(1.66 \mathrm{~g} / \mathrm{l})$ in distilled water.

Medium 7 is made up from the stock solutions prior to use by mixing stock $A(200 \mathrm{ml})$, stock B $(20$ $\mathrm{ml})$, stock C (1 ml), stock D $(4 \mathrm{ml})$, and distilled water $(775 \mathrm{ml})$.

Medium 8: tryptose (Difco) $(2 \mathrm{~g} / \mathrm{l})$, yeast extract (Difco) $(1 \mathrm{~g} / \mathrm{l})$, maltose $(0.5 \mathrm{~g} /$ 1), L-cystin $\cdot \mathrm{HCl}(0.1 \mathrm{~g} / \mathrm{l})$, and Lascorbic acid $(0.02 \mathrm{~g} / \mathrm{l})$ were dissolved in distilled water and the $\mathrm{pH}$ of the solution adjusted to 6.0 with $\mathrm{HCl}$. The solution was then autoclaved for $10 \mathrm{~min}$ at $121^{\circ} \mathrm{C}$, and horse serum $(10 \mathrm{ml})$ inactivated at $56^{\circ} \mathrm{C}$ for $30 \mathrm{~min}$ was added to 11 of the solution together with Na-penicillin (100.000 units) and streptomycin sulfate $(0.1 \mathrm{~g})$ in $1 \mathrm{ml}$ of distilled water.

All media were autoclaved for $20 \mathrm{~min}$ at $121^{\circ} \mathrm{C}$ before use.

\subsection{Cultivation and assay}

Testing of bacteria listed in Table I for production of an $\alpha$-acetolactate decarboxylase was, except in those cases mentioned specifically, performed by inoculating $10 \mathrm{ml}$ portions of medium 1 or 2 and incubation of the resulting cultures without shaking or aeration for 24 hours at the optimal temperature for each particular strain. $1 \mathrm{ml}$ aliquots of the resulting cultures were then transferred to $10 \mathrm{ml}$ portions of fresh media which were incubated for another 24 hours at the same temperature. The cells were isolated by centrifugation and suspended in $1 \mathrm{ml} 5.4 \mathrm{M}-\mathrm{NaCl}$ in $5 \mathrm{~mm}$-phosphate buffer at $\mathrm{pH} 6.2$ and treated with ultrasound while cooled in ice for two $10 \mathrm{sec}$ periods using an MSE 4/75/MK 2 instrument. Portions ( 50 and $100 \mu \mathrm{l})$ of the resulting suspension of disrupted cells were applied for enzyme assay as described previously (6). Strains of Clostridia and Micrococcus were tested after growth in medium 3 and 6 , respectively. Trichomonas species were tested after growth in medium 8 and Microcystis aeruginosa after cultivation in medium 7 .

The fungi listed in Table II were cultivated at $22{ }^{\circ} \mathrm{C}$ in $250 \mathrm{ml}$ flasks using orbital shakers and media 1, 2, 4 or 5. The biomass produced was isolated when well established growth had been achieved whereupon the isolated cells were disrupted and tested as indicated above.

\section{RESULTS AND DISCUSSION}

From Table I which summarizes results of tests carried out on 325 bacterial strains from 79 species, 34 genera and 16 families it is apparent that the ability to produce $\alpha$-acetolactate decarboxylases is a widespread property among bacteria: The decarboxylase activity was detected in preparations of no less than 11 families, 20 genera, and 40 different bacterial species. Among these 6 families, 13 genera, and 34 species have previously not been described as beeing sources of the decarboxylase. A number of bacterial strains tested were found not to generate any acetolactate decarboxylase activity: Members of 15 families, 26 genera, and 56 species were thus found devoid of the decarboxylase activity when tested after cultivation under the conditions applied for the tests.

It is difficult, however, to evaluate the significance of the negative findings indicated in Table I. It was thus constantly found that the quantity of the acetolactate decarboxylase generated by the various strains listed in Table I depended upon the cultivation medium. However, the medium providing the highest yield differed from strain to strain. Also, in a few cases where the time course of the generation of acetolactate decarboxylase was monitored it was found that the yield of decarboxylase depends upon the time of 
Table I.

Results of assays of 79 bacterial species for production of $x$-acetolactate decarboxylase activity. The number of strains found to generate the decarboxylase activity are listed as positive (pos.), while the number of strains found not to generate any decarboxylase activity are listed as negative (neg.). Also given is the average number of units generated by positive strains in $10 \mathrm{ml}$ of medium under the conditions applied for the assay.

Pseudomonadaceae

Rhizobiaceae

Halobacteriaceae

Achromobacteriaceae

Enterobacteriaceae

Chromobacteriaceae

Vibrionaceae

Neisseriaceae

Micrococcaceae

Streptococcaceae
Pseudomonas aeruginosa

Pseudomonas fluorescens

Pseudomonas maltophila

Pseudomonas viridiflava

Gluconobacter oxydans

Agrobacterium tumefaciens

Acetobacter xylinum ATCC 10245

Achromobacter metalcaligenes

Acinetobacter sp.

Alcaligenes faecalis

Citrobacter bal. bethesda

Enterobacter aerogenes

Enterobacter agglomerans

Enterobacter cloaceae

Enterobacter sp.

Erwinia sp.

Escherichia coli

Klebsiella aerogenes

Klebsiella pneumoniae

Proteus inconstans

Proteus mirabilis

Proteus morganii

Proteus vulgaris

Serratia marcescens

Serratia plymuthica

Yersinia enterocolitica

Chromobacterium lividum

Chromobacterium violaceum

Aeromonas hydrophila, NCIB 9237

Aeromonas hydrophila

Aeromonas liquefaciens

Aeromonas sp.

Vibrio parahaemolyticus

Flavobacterium meningosepticum

Flavobacterium sp.

Micrococcus luteus

Micrococcus sp.

Staphylococcus epidermidis

Staphylococcus sp.

Streptococcus agalactiae

Streptococcus bovis

Streptococcus casei

Streptococcus cremoris

\begin{tabular}{|c|c|c|}
\hline pos. & neg. & $\mathrm{U} / 10 \mathrm{ml}$ \\
\hline & 4 & \\
\hline & 1 & \\
\hline & 1 & \\
\hline 1 & & 10 \\
\hline 1 & & 27 \\
\hline & 1 & \\
\hline 1 & & 50 \\
\hline 1 & 2 & 8 \\
\hline & 1 & \\
\hline & 1 & \\
\hline & 3 & \\
\hline 1 & 1 & 56 \\
\hline 4 & 2 & 32 \\
\hline 2 & 1 & 42 \\
\hline 3 & 4 & 20 \\
\hline & 1 & \\
\hline & 6 & \\
\hline 1 & & 73 \\
\hline & 1 & \\
\hline & 1 & \\
\hline 1 & 1 & 11 \\
\hline & 1 & \\
\hline & 4 & \\
\hline 1 & & 22 \\
\hline 1 & & 6 \\
\hline & 1 & \\
\hline 1 & & 11 \\
\hline & 1 & \\
\hline 1 & & 40 \\
\hline 5 & 2 & 29 \\
\hline 2 & & 47 \\
\hline 7 & 1 & 50 \\
\hline 1 & & 16 \\
\hline & 1 & \\
\hline & 1 & \\
\hline 1 & 1 & 26 \\
\hline & 3 & \\
\hline & 1 & \\
\hline & 1 & \\
\hline 1 & 1 & 9 \\
\hline & 1 & \\
\hline & 2 & \\
\hline 1 & 7 & 6 \\
\hline
\end{tabular}




\begin{tabular}{|c|c|c|c|c|}
\hline & Streptococcus durans & & 1 & \\
\hline & Streptococcus diacetylactis & 38 & 2 & 5 \\
\hline & Streptococcus faecalis & & 3 & \\
\hline & Streptococcus faecium & 2 & 3 & 28 \\
\hline & Streptococcus lactis & & 6 & \\
\hline & Streptococcus thermophilus & & 2 & \\
\hline & Streptococcus uberis & 1 & & 12 \\
\hline & Streptococcus sp. & & 1 & \\
\hline \multirow[t]{22}{*}{ Bacillaceae } & Bacillus brevis ATCC 8185 & 1 & & 12 \\
\hline & Bacillus cereus & 8 & 5 & 17 \\
\hline & Bacillus cirkulans & 1 & & 43 \\
\hline & Bacillus licheniformis NCIB 8061 & 1 & & 30 \\
\hline & Bacillus licheniformis & 9 & & 26 \\
\hline & Bacillus macerans & 1 & & 38 \\
\hline & Bacillus megatherium ATCC 10778 & 1 & & 10 \\
\hline & Bacillus polymyxa NCIB 8523 & 7 & & 27 \\
\hline & Bacillus polymyxa & 2 & 1 & 12 \\
\hline & Bacillus subtilis NCIB 8565 & 1 & & 18 \\
\hline & Bacillus subtilis NCIB 8646 & 1 & & 12 \\
\hline & Bacillus subtilis ATCC 6633 & 1 & & 4 \\
\hline & Bacillus subtilis NCIB 8646 & & 1 & \\
\hline & Bacillus subtilis & 3 & 6 & 15 \\
\hline & Bacillus sp. & & 4 & \\
\hline & Clostridium acetobutyricum & & 3 & \\
\hline & Clostridium bifermentans & & 6 & \\
\hline & Clostridium histolyticum & & 1 & \\
\hline & Clostridium innocum & & 1 & \\
\hline & Clostridium perfringens & & 9 & \\
\hline & Clostridium propionicum & & 2 & \\
\hline & Clostridium sporogenes & & 2 & \\
\hline \multirow[t]{12}{*}{ Lactobacillaceae } & Lactobacillus acidophilus & 2 & 3 & 27 \\
\hline & Lactobacillus brevis & & 1 & \\
\hline & Lactobacillus buchneri & & 1 & \\
\hline & Lactobacillus bulgaricus & & 1 & \\
\hline & Lactobacillus casei ATCC 7469 & 1 & & 10 \\
\hline & Lactobacillus fermentum ATCC 9338 & & 1 & \\
\hline & Lactobacillus fructivorans & 1 & & 6 \\
\hline & Lactobacillus helveticus & & 4 & \\
\hline & Lactobacillus lactis & 1 & 1 & 20 \\
\hline & Leuconostoc citrivorum & & 2 & \\
\hline & Leuconostoc cremoris & & 1 & \\
\hline & Leuconostoc mesenteroides & 1 & & 8 \\
\hline \multirow[t]{5}{*}{ Corynebacteriaceae } & Brevibacterium divaricatum & & 1 & \\
\hline & Cellulomonas flavigena & 1 & & 12 \\
\hline & Corynebacterium equi & 1 & & 8 \\
\hline & Corynobacterium renale & 1 & & 23 \\
\hline & Microbacterium thermosphactum & 1 & & 8 \\
\hline \multirow[t]{2}{*}{ Propionibacteriaceae } & Propionibacterium freudenreichii & & 1 & \\
\hline & Propionibacterium sp. & & 2 & \\
\hline Mycobacteriaceae & Mycobacterium phlei & & 1 & \\
\hline Streptomycetaceae & Streptomyces sp. & & 49 & \\
\hline
\end{tabular}


S.E. GodTFREDSEN et al.: Distribution of $x$-acetolactate decarboxylases among microorganisms

Table II.

Fungi (58 Species) tested and found devoid of $\alpha$-acetolactate decarboxylase activity.

\section{PHYCOMYCETES}

Mucorales

ASCOMYCETES

Hysterales

Pezizales

Helotiales

Eurotiales

Sphaeriales

Pseudosphaeriales

Endomycetales
Rhizopus nigricans

Syncephalastrum racemosum

Cunninghamella blakesleana

Mucor mucedo

Phycomyces blakesleanus

Thamnidium elegans

Hysterium incidens

Ascodesmus nigricans

Botrytis allii

Sporonema hiemale

Monascus ruber

Byssochlamus fulva

Emericellopsis salmo

synnematum

Wardomyces anomale

Ceratocystis piceae

Neurospora crassa

Sepedonium chrysospermum

Chaetomium globosum

Hypomyces solani

Pleospora herbarum

Dipodascus aggregatum

Ascoidea rubescens

Schizosaccharomyces pombe

Saccharomyces fragilis

Saccharomyces pastorianus

\section{BASIDIOMYCETES}

Schizophyllum commune

Fomes annosus

Ustilago nigra

\section{FUNGI IMPERFECTI}

Sphaeropsidales

Chaetomella terricola

Septoria digitalis

Diplodia frumenti

Phoma terrestris

Conothyrium carpaticum

Melanconiales Myrothecium roridum

Pestalotia viridis

Melanconium juglandinum

Epicoccum andropogonis

Moniliales

Penicillium brevi-compactum

Penicillium patulum

Aspergillus clavatus

Aspergillus niger

Sepedonium spermum

Fusidium coccineum

Oidiodendron echinulatum

Cephalosporium acremonium

Cephalosporium spinosum

Scopulariopsis brevicaulis

Paecilomyces marquandii

Verticillium albo-atrum

Tricothecium roseum

Pullularia pullulans

Monotospora brevis

Cladosporium elatum

Helminthosporium solani

Chrysosporium keratophilum

Torulopsidales

Rhodotorula ubra

Kloeckera apiculata

Geotrichum candidum

Unidentified sp. $\quad 38$ harvesting. Thus, it might be possible to identify conditions under which strains listed as negative in Table I would in fact be able to generate some acetolactate decarboxylase activity.

On the basis of the data given in Table I it seems likely, however, that the ability to produce acetolactate decarboxylase activity is a property associated with certain strains within the families Pseudomonadaceae, Halobacteriaceae, Achromobacteriaceae, Enterobacteriaceae, Chromobacteriaceae, Vibrionaceae, Micrococcaceae, Streptococcaceae, Bacillaceae, Lac- tobacillaceae, Corynebacteriaceae and a property not generally associated with specific genera within each family. For example, among Lactobacillaceae both positive and negative members of the genus Lactobacillus as well as of Leuconostoc were detected, and some strains of Lactobacillus acidophilus were found to be negative while others were found to be positive. In the case of Bacillaceae no positive strains of Clostridia were detected while most strains of Bacillus tested were found to be positive. As regards Bacillus licheniformis all strains tested 
were found to produce the decarboxylase while positive as well as negative strains of Bacillus subtilis and Bacillus cereus were identified. The strain dependence of the ability to generate $\alpha$ acetolactate decarboxylase activity may explain the apparent discrepancy between some results indicated in Table I and those of SPECKMAN who detected $\alpha$-acetolactate decarboxylase activity in preparations of Leuconostoc citrovorum (11) and Chuna who found the decarboxylase activity in preparations of Pseudomonas fluorescens, Lactobacillus brevis, and Streptococcus lactis (2).

The major groups of microorganisms may be grouped and ordered as indicated in Table III. For the purpose of completeness of the screening work according to this grouping a series of microorganisms including Fungi (Table II), Algae, (Microcystis aeruginosa, Nitschia palea, Euglena gracilis), and Protozoa (Tricomonas foetus and Tetrahymena pyriformis) were tested for $\alpha$ acetolactate decarboxylase activity. In contrast to the finding that the procaryotic bacteria frequently produce acetolactate decarboxylase activity no such activity was detected in preparations of these various eucaryotic microorganisms. One may, therefore, as indicated in Table III, tentatively derive a preliminary picture of the distribution of $\alpha$-acetolactate decarboxylase among microorganisms: Only certain bacteria, including Corynebacteria, were found to generate the decarboxylase while other bacteria as Mycobacteria and Streptomycetes as well as Fungi, Algae, and Protozoa did not generate acetolactate decarboxylase activity. The ability to produce this decarboxylase appears, therefore, to be a property of only procaryotes.

The yields of the acetolactate decarboxylase activity obtained per $10 \mathrm{ml}$ of growth medium under the conditions applied during the screening work are indicated in Table I. These yields do not indicate the maximum yields that can be obtained from each individual strain through variations of, for example, fermentation conditions or time harvesting and, therefore, do not, necessarily, indicate which of the various possible bacteria may be most suitable for use in an industrial process.

In order to obtain higher yields of the decarboxylase from the bacteria listed in Table $I$ it is desirable to understand the role of the decarboxylase in the metabolism of the bacterial cell. A comparison of the physiological properties of the 20 genera generating the decarboxylase when tested provides, however, only limited information in this respect. A common feature of the genera producing the decarboxylase is the ability to utilize citrate as a carbon source. Moreover, most genera found to produce the decarboxylase are catalase positive as well as VP-positive bacteria and are able to utilize ammonium salts as a nitrogen source. The ability to utilize citrate as carbon source is, however, also a property of species which have been found not to produce acetolactate decarboxylases and some VP-positive species found not to generate any acetolactate decarboxylase activity have likewise been identified.

In bacterial cells citrate is converted into acetic acid and oxaloacetic acid which, in turn, is decarboxylated to pyruvic acid (Scheme 1). This keto-acid is decarboxylated to provide the thiamine pyrophosphate of acetaldehyde which, by condensation with pyruvate, provides acetolactate (4). This pathway of pyruvate and acetolactate biosynthesis differs from the glycolytic pathway leading from glucose to pyruvate (4) in the sense that no NADH is generated during the course of pyruvate generation from citrate whereas 2 moles of the reduced cofactor is generated for every mole of glucose converted. A cell generating its pyruvate from glucose need, therefore, to reduce most of the keto-acid to lactic acid in order to regenerate its NADH. The ability to utilize citrate for biosynthesis of pyruvate does therefore imply an advantage to the

Table III.

Grouping of microbial organisms, genophore, and occurrence of $\alpha$-acetolactate decarboxylase activity. Groups, some members of which have been found to generate $x$-acetolactate decarboxylase activity are marked + .

\begin{tabular}{llc}
\hline Group & Genophore & Activity \\
\hline Bacteria & Prokaryota & + \\
Fungi & Eukaryota & - \\
Algae & Eukaryota & - \\
Protozoa & Eukaryota & - \\
\hline
\end{tabular}


Scheme 1.

Key products involved in pyruvate biosynthesis and conversion.

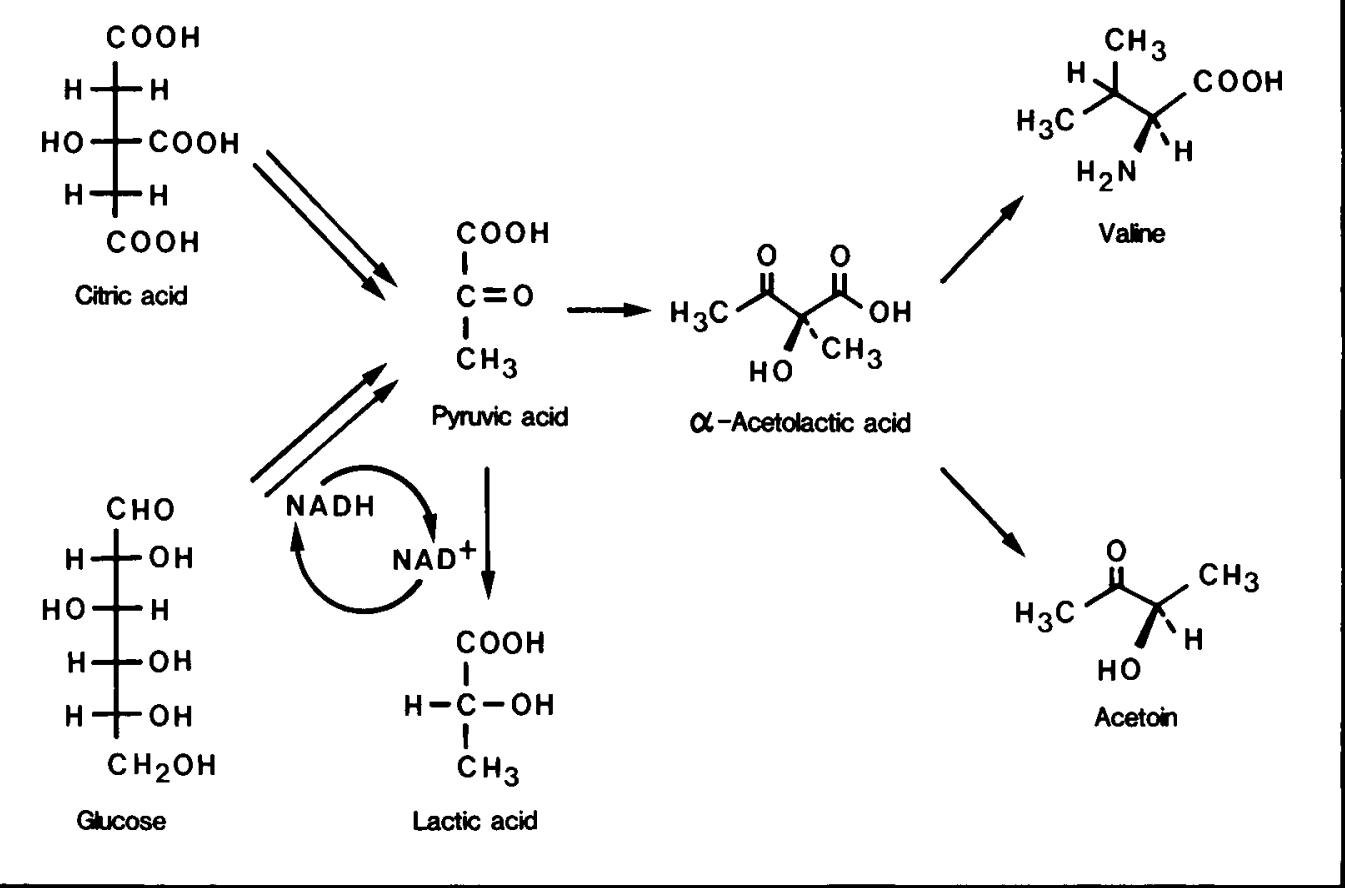

cell since this pathway may be utilized for biosynthesis of pyruvate freely available for other purposes within the cell (4). The ability to synthesize such "excess pyruvate" may, however, also create problems within the cell for example in respect to control of valine biosynthesis. In yeast, which does not generate any acetolactate decarboxylase activity (4) the biosynthesis of this amino acid is controlled by feed-back inhibition on the acetolactate synthetase $(9,10)$. This property of the yeast cell may in fact be utilized to supress acetolactate and diacetyl generation during fermentation of wort. In microorganisms capable of producing pyruvate from citrate this control mechanism of valine biosynthesis may not be sufficient. In Streptococcus diacetylactis which does produce $\alpha$-acetolactate decarboxylase activity, the acetolactate synthetase is not inhibited by valine (4) and in Enterobacter aerogenes which, likewise, generates the decarboxylase, two acetolactate synthetases have been identified one of which is inhibited by valine while the other is not (7). Acetolactate decarboxylases may thus have been introduced into these microorganisms for the purpose of controlling the flow of acetolactate generated from excess pyruvate. The function of the decarboxylase might also be to remove acidic products and thus to increase the $\mathrm{pH}$ during growth of the acetolactate decarboxylase producing microorganism or it may contribute to NAD-regeneration in such cells since acetoin produced during the decarboxylation may readily be reduced to 2,3-butanediol. Clearly, the role of the acetolactate decarboxylase in bacteria is still a matter of speculation. The close link between acetolactate, citrate metabolism and valin biosynthesis makes it quite likely, however, that it will be possible to control the biosynthesis and thus to increase the yield of acetolactate decarboxylases by adjusting the conditions applied for fermentation of acetolactate decarboxylase producing microorganisms and by applying appropriate mutants of such microorganisms.

If $\alpha$-acetolactate decarboxylases are to be used for beer production it is preferable that the source of the decarboxylase has acceptance within the food industry. In this respect many of the 
decarboxylase generating bacteria listed in Table I are not suitable, but some are. It is thus especially noteworthy that species of Bacillus licheniformis as well as of Lactobacillus generate $\alpha$-acetolactate decarboxylase activity. Species of Lactobacillus are used to a large extent in the dairy industry and Bacillus licheniformis is a GRAS-microorganism extensively used for production of enzymes used within the food industry. The finding that acetolactate decarboxylase activity is generated by these bacteria makes it likely, therefore, that it will be possible to produce a decarboxylase attractive for application in brewing.

\section{ACKNOWLEDGEMENTS}

The authors are indebted to LILLIAN ABILDgaArd, Sussi Dohn and Gunilla Trolle for enthusiastic technical assistence. The authors would also like to thank ANNE MuNCH RASMUSSEN for testing a series of strains of Streptococcus diacetylactis.

\section{REFERENCES}

1. Branen, A.L. \& T.W. Keenan: Biosynthesis of $x$-acetolactate and its conversion to diacetyl and acetoin in cell-free extracts of Lactobacillus casei. Can. J. Microbiol. 8, 480-485 (1972)

2. Chuang, L.F. \& E.B. Collins: Biosynthesis of diacetyl in bacteria and yeast. Journal of Bacteriology 95, 2083-2089 (1968)

3. Chuang, L.F. \& E.B. Collins: Inhibition of diacetyl synthesis by valine and the roles of $x$ - ketoisovaleric acid in the synthesis of diacetyl by Saccharomyces cerevisiae. J. Gen. Microbiol. 72, 201-210 (1972)

4. Collins, E.B.: Biosynthesis of flavor compounds by microorganisms. Journal of Dairy Science 55, 1022-1028 (1972)

5. Collins, E.B. \& R.A. Speckman: Evidence for cellular control in the synthesis of acetoin or $x$ ketoisovaleric acid by microorganisms. Can. J. Microbiol. 20, 805-811 (1974)

6. Godtrredsen, S.E. \& M. Ottesen: Maturation of beer with $x$-acetolactate decarboxylase. Carlsberg Res. Commun. 47, 93-102 (1982)

7. JUNI, E.: Mechanisms of formation of acetoin by bacteria. J. Biol. Chem. 195, 715-734 (1952)

8. Løken, J.P. \& F.C. Størmer: Acetolactate decarboxylase from Aerobacter aerogenes. Purification and Properties. Eur. J. Biochem. 14, 133-137 (1970)

9. Magee. P.T. \& H. De Robichon-Szulmajster: The regulation of isoleucine- valine biosynthesis in S. cerevisiae. III. Properties and regulation of the activity of acetohydroxy acid synthetase. Eur. J. Biochem. 3, 507-511 (1968)

10. Owades, J.L., L. Maresca \& G. Rubin: Nitrogen metabolism during fermentation in the brewing process. II. Mechanism of diacetyl formation. Am. Brew. 93, 24-26 (1960)

11. Speckman, R.A. \& E.B. Collins: Diacetyl biosynthesis in Streptococcus diacetilactis and Leuconostoc citrovorum. Journal of Bacteriology 95 , 174-180 (1968)

12. WATT, D. \& L.O. Krampitz: $\boldsymbol{x}$-Acetolactic acid, an intermediate in acetylmethylcarbinol formation. Fed. Proc. 6, 301 (1947) 